\title{
Printed music papers: research opportunities and challenges
}

John Milsom

From at least the 1530s onwards, European music manuscripts were sometimes copied on papers printed with staves and tablature grids. ${ }^{1}$ The existence of this kind of stationery in an age of widening musical literacy should come as no surprise. Printed music papers bearing staves or tablature grids were cheap and easy to make, they were convenient for users, and they met an obvious and perennial need among amateur and professional musicians alike, whether for assembling personal or local repertories, or for the acts of composing, arranging or transmitting musical works. Printed music papers were available in sixteenthcentury Italy, Spain, France, the Low Countries, Germany, England and Sweden; they could probably also be bought elsewhere. ${ }^{2}$ The only surprise is that they have been observed so rarely, and are sometimes completely overlooked. Admittedly the inattentive eye can easily miss the presence of printed staves, especially when viewing an item from a surrogate such as a monochrome photograph or microfilm. To an extent, however, printed staves have probably often been passed over in silence because, as matters stand, it can be hard to know what to make of them or say about them, beyond merely noting their existence.

One reason for this general neglect is that printed music papers are not easy to attribute or catalogue. Almost none bears the name or initials of its printer, and they never record either the date of printing or the place of printing. Only through other evidence can they sometimes be located in geographical or chronological context. Moreover, printed music papers are cumbersome to describe because their characteristics need to be defined numerically, by counting or measuring the number of staves or grids per page, the height of the individual staff, the length of the staves, and the total height of the printed area. Watermarks can sometimes add evidence, and a few designs have ornamental borders or frames around the staves. However, most printed music papers are plain, anonymous and frankly inscrutable.

In this study, I point to some ways in which research in this field can be moved forward in an age of rapidly increasing online availability of digital images. Tasks that once required the researcher to visit libraries take careful notes and order bespoke photography can now be done easily and quickly on a computer screen. Moreover, access to digital images encourages new ways of researching and thinking. For instance, a digital copy of a physical object can be dismembered, and its component parts reassembled on the screen to permit comparisons. High-resolution images can be magnified to allow the study of detail. A screen can easily accommodate images of items scattered across the world's libraries. Questions remain about how best to accumulate, share and interpret the resulting data, but nonetheless the research opportunities are fairly transparent.

This chapter examines two sample groups of printed music papers in order to develop these arguments. Both groups encompass only papers printed with five-line staves for 
mensural notation. Tablature grids are omitted here for reasons of space, but the research methods proposed below would be equally applicable to them. The first sample group came into existence under the terms of a royal licence granted in 1575 to two English musicians, Thomas Tallis and William Byrd, which gave them exclusive national rights to print, import and sell 'ruled paper imprinted' for a period of twenty-one years, that is, from 1575 to $1596 .{ }^{3}$ When their printed papers were first identified and described by Iain Fenlon and myself, as part of a report published in 1984, we drew our data direct from the physical books, which we consulted in the libraries where they are kept. ${ }^{4}$ Most of these same books can now be viewed online in high-resolution digital images, accessible via the Digital Image Archive of Medieval Music (DIAMM). These images make it clear that we overlooked evidence that sheds light not only on Tallis and Byrd's output of printed papers, but also (and more importantly) on the manuscripts that were made from them. The second sample group, briefly mentioned in our 1984 report but not researched there, is drawn from manuscripts now in the care of the Bayerische Staatsbibliothek, Munich. They date apparently from the 1540s; some, if not all of them, once belonged to the Augsburg bibliophile Hans Heinrich Herwart (1520-1583). ${ }^{5}$ These items also use printed music papers, and digital images are available for free download from the Staatsbibliothek's website. The time is therefore ripe to look afresh at them, and ask what more might be learnt about their provenance history.

The methods used to create music paper need a brief introduction. ${ }^{6}$ In principle, two technologies were available: printing from woodblocks, and printing from metal. For the latter, there were at least three options. The first and commonest, here called the 'integral-staff' method, required the printer either to cast whole staves, or to assemble each staff out of five long metal rules, and to bond or fuse those rules together in some way. (No physical examples of such staves are known to survive, so the method of manufacture is unclear, though the subject could probably sustain more research.) The rules themselves may have been made from a variety of metals, including durable brass. ${ }^{7}$ Most, however, were clearly vulnerable to damage, because over time each staff-line typically acquired small bends, splays and splits. ${ }^{8}$ The evolving identity of these physical objects makes it possible to research the life-history of an individual staff that was re-used multiple times. The second option was available to any printer who owned a font of so-called 'nested' music type, a technology in which each type bearing a music symbol is minimally embedded in staff-lines. ${ }^{9}$ Here, the compositor had access to a wide selection of short single rules of varying lengths, into which the sorts for musical characters were fitted. These same short rules could also be assembled to create whole blank staves. Music paper made this way uses the 'nested' method. A third option for printing staves was the 'cast-type' method. When a new music font of standard linear music type was devised, the punchcutter by necessity had to design short segments of blank staff for insertion between symbols, and for filling out the final staff of a composition. ${ }^{10}$ He would therefore cut punches for staff-segments in a variety of lengths, and create matrices from which the resulting type could be cast. Multiple castings of the longer segments could then be abutted to form whole staves, and in theory these could be used to print music paper. ${ }^{11}$ Whole blank staves assembled from cast type often feature in books of printed polyphony, sometimes even whole pages of them. However, there is little evidence that this technique was used to print sheets intended solely for separate sale and manuscript use.

At the printing shop, the compositor first had to assemble staves of near-identical height and width, typically twenty or so. He then imposed them as a single forme, which would 
serve to print both sides of the sheet. If imposing in folio format, the staves would be arranged in two tall columns separated by a central space. When printed, the sheet would be identical on both its sides, and when folded on its vertical (shorter) axis, it would produce a bifolium (two leaves, four pages). If working in oblong quarto format, the compositor would fill each quarter of the forme with a block of between three and six staves. The finished sheet, again identically printed on both its sides, would be folded twice, first on its horizontal (longer) axis, then on its vertical axis, giving rise to four-leaf (eight-page) gathering. After printing, when the contents of the forme were washed and distributed, the staves might be set aside for re-use. This last action would ease the task of making a new edition, because only minutes were needed to re-impose the staves in the forme and resume printing. In less than a day, many hundreds of sheets could be printed on both sides from a freshly re-imposed forme. If the format were oblong quarto, then 500 sheets would generate 1,000 bifolia (4,000 pages) of printed staves. If the printer supplied stationers as well as selling from his own premises, then demand might be sufficiently high for multiple editions of a stable design to be printed and issued over the course of a year or several years. ${ }^{12}$

The notion of 'editions' of a stable design is also explored here, using the Tallis-Byrd papers in oblong quarto format as an example. ${ }^{13}$ These sheets were manufactured using the integral-staff method, drawing on more than twenty near-identical metal-rule staves that were reserved after each printing. When a new edition was needed, the staves were set once again in the forme. However, this happened each time in a random new order (each staff being notionally identical), and with the staves inverted at random (each staff being symmetrical). Because most of the staves have characteristic dents and splays, different editions of a stable and repeatable design can easily be distinguished from one another. To an extent, we may even place them in chronological order on the basis of the evolving damage to individual staves. The editions themselves are of course undated, but sometimes they can be assigned approximate dates from the repertory copied into them.

Research into printed music papers therefore needs to proceed at five different levels. The first level addresses production technique, which might be woodblock, integral-staff, nested or cast-staff. The second level identifies the design, determined by the number of staves per page, the height and length of the staff, the total height of the printed area, and possibly indentation of the uppermost staff. The third level seeks to identify different editions of a stable design, if and when they exist. This is done by working at the fourth and most detailed level, which involves identifying individual staves on the basis of their idiosyncrasies and defects. If the same staves were used to create more than one design for instance, both quarto and folio layouts - then in effect we also face the concept of brand: multiple related products made and issued by the same manufacturer. Production technique is easily described in words, and designs are defined by measurement, but the analysis of brand, editions and staff-characteristics is more challenging. Some suggestions for procedure are offered below.

\section{The Tallis-Byrd quarto papers}

Printed music papers were commonly used in England from the 1560s onwards. Trade in this commodity was therefore well established when Tallis and Byrd gained control over it in $1575 .{ }^{14}$ We know that the two men took advantage of their royal privilege. In 1577, a group of London printers and booksellers objected to the fact that 'One Byrde a singingman hathe a licence for ... the printing of ruled paper', which implies that at 
least one of them resented the monopoly. ${ }^{15}$ In 1582 Christopher Barker, queen's printer and Upper Warden of the Stationers Company, reported to the queen's chief counsellor, Lord Burghley, that the Tallis-Byrd printed music papers were, by the standards of the day, moderately profitable, or 'somewhat beneficial', as Barker put it. ${ }^{16}$ In London, at least around 1583, the papers were available from the printer-bookseller Henry Bynneman (discussed below), and they could also probably be bought from stationers elsewhere in the country. For instance, an inventory of the stock of the Cambridge bookseller John Denys in 1578 included ' 2 queris [quires] of paper ruled' ${ }^{17}$ The 'Sitherne book ruled' stocked by the Shrewsbury bookseller Roger Ward in 1585 was probably made of printed paper for cittern or gittern tablature. ${ }^{18}$ By law, these papers, if printed rather than hand-ruled, could only have been supplied by Tallis, Byrd, or assigns such as Bynneman, from 1575 until expiry of the licence in 1596.

Three late sixteenth-century sets of partbooks use the Tallis-Byrd quarto paper. Close study reveals that, between them, they were in fact made from no fewer than fifteen different editions of a stable design, each with the staves differently configured in the forme. Since the spacing between the staves remains unchanged, it would seem that, between editions, not only the staves but also the segments of spacing furniture were reserved for re-use when required. ${ }^{19}$ It is not known who actually owned these materials. They may have stayed with the printer, or passed between printers, or may have been the property of Tallis (d. 1585) and Byrd, who handed them over to a printer only when a new edition was needed. Certainly this would have protected them from illicit undeclared editions made by unscrupulous hands. ${ }^{20}$

The partbook set most securely copied on the Tallis-Byrd quarto paper is GB-Och Mus. 979-983, which was compiled over the course of several decades, probably from the 1570s onwards. ${ }^{21}$ Formerly a set of six volumes but now lacking its Tenor, these important books are the main and often unique source of many Latin-texted compositions by Thomas Tallis, John Sheppard, William Byrd and their contemporaries. They were copied by John Baldwin, a professional church singer and music scribe. Baldwin probably knew Byrd personally. Certainly he had access to rare and unpublished compositions by Byrd, including juvenilia, and he was the copyist of 'My Ladye Nevells Booke', a superb and authoritative manuscript copy of Byrd's keyboard works up to 1591. His partbooks, cited below as Baldwin, use a total of nine different editions of the quarto paper. This shows that Baldwin was repeatedly able to acquire new sheets of a stable design over the course of more than a decade. Baldwin's proximity to Byrd suggests that he is unlikely to have used an unauthorised product sourced from an underhand dealer. For that reason, his printed papers can confidently be linked with the Tallis-Byrd licence.

Two further partbook sets make use of this design of music paper. One of them, GB-Och Mus. 984-988, is a set of five partbooks copied by Robert Dow (1553-1588), a universityeducated lawyer and fellow of All Souls College, Oxford, who was also skilled in calligraphy. This set, designated below as Dow, bears the copying date 1581. Dow uses another edition of the quarto design, this time with the staves printed in red ink. ${ }^{22}$ The third set survives incomplete; only two partbooks now exist of what was once probably a set of six. The Superius is in private ownership (the 'McGhie MS', formerly known as the 'James MS'); the Discantus is GB-Ob MS Tenbury 389.23 This set, designated below as McGhie/T389, was compiled by various unidentified copyists during the last quarter of the sixteenth century, and makes use of six different editions of the basic quarto design. One of the editions used in McGhie/T389 also occurs in Baldwin, so the total number of editions present within these three partbook sets is fifteen, not sixteen. 
The editions were researched by first identifying individual staves, then watching for their changing placement within the forme in each edition. For ease of reference and to aid memory, each staff was named using a neutral four-letter noun ('BARD', 'HOST', 'KING', etc.), and an image library created, showing each distinctive staff in both its inversions. Using these images and names, each edition was then analysed by charting the placement of individual staves within the forme. Diagrams were drawn of the sheets as printed - four blocks each of five staves, identically printed on both sides of the sheet - and the staves identified by their four-letter names. A decision was made not to number the resulting editions, since numbers might misleadingly imply a chronological relationship. Instead, each edition was named using a neutral and memorable three-letter noun, such as 'CAT', 'ELK' and 'OWL'.

Using these methods, a comprehensive overview was made of the fifteen different editions of the Tallis-Byrd quarto paper found in Baldwin, Dow and McGhie/T389. This, in turn, allowed a better understanding of the partbooks themselves. Of them, the most straightforward is Dow. This set, which Dow apparently copied for his personal use, includes preplanned layers of motets, anthems, consort music, and consort songs for voices and viols. It is a major source of Byrd's works, especially his songs. Dow acquired his ruled paper as a batch of a single edition. The fact that the staves are printed in red might even imply that the edition was custom-printed for him. Dow seems to have bought exactly 5 quires of this paper, one 24-sheet quire for each partbook. With the sheets folded into quarto, each partbook therefore comprises 24 gatherings, 96 leaves and 192 pages. Dow evidently began copying the partbooks in or around 1581, the date recorded on the first page of each book.

We can estimate how much Dow paid for his printed paper by turning to an inventory of the possessions of the London printer-bookseller Henry Bynneman, who seems to have acted as retail agent for Tallis and Byrd. ${ }^{24}$ On his death in 1583, Bynneman held a stock of 'twenty foure Remes of ruled paper', valued at $£ 4.16 \mathrm{~s}$ (= 1152d). ${ }^{25}$ An English ream numbered 480 sheets. ${ }^{26}$ Bynneman had twenty-four reams in stock, so his holdings were in the region of 11,520 sheets. At a total value of $£ 4.16 \mathrm{~s}(=1152 \mathrm{~d})$, this works out at $0.1 \mathrm{~d}$ per sheet. It is not known whether the valuations of Bynneman's stock represent estimates of wholesale or cost prices. ${ }^{27}$ Either way, however, these valuations could realistically be quadrupled to achieve retail price, leading to a maximum estimate of $0.4 \mathrm{~d}$ per sheet. ${ }^{28}$ This is less than the price typically asked for 'broadside' ballad sheets, which were printed on one side only. In the sixteenth century, such ballad sheets cost between a halfpenny and a penny $(0.5 \mathrm{~d}-1 \mathrm{~d}) .^{29}$ Using this estimated price of $0.4 \mathrm{~d}$ per sheet, we can calculate that Dow spent around four shillings on acquiring his ruled paper, assuming that it came from stock. If it was printed with red staves on commission, the price might have been higher. Had Dow returned to Bynneman's shop two years later to purchase another 120 sheets, he would have found there 11,520 sheets waiting for sale. Assuming that all these sheets were printed in quarto format, this would have been sufficient to make ninety-six partbook sets of the size of Robert Dow's. Thus for the first time we gain some idea of the economics and sheer scale of printing music papers in late Tudor England. Tallis and Byrd presumably took a share of the profits, so the business must indeed have been 'somewhat beneficial' to them.

Compared with Dow, the Baldwin set of partbooks is bibliographically complex. Baldwin began his project by making ad hoc gatherings that he may not have meant originally to collect into bound partbooks. As his collection grew, however, Baldwin's expansions became more organised, and eventually he amalgamated all the layers, so that the contents follow on from one another continuously without breaks. This required him to excise 
certain leaves, and to re-copy some pages on fresh paper, actions that contributed to the bibliographical complexity of the finished books. ${ }^{30}$ In total, Baldwin drew on nine different editions of the Tallis-Byrd paper, which he acquired over the course of perhaps two decades. The stability of the basic design over such a long period may imply that Tallis and Byrd were sensitive to the needs of a scribe such as Baldwin, who might expect the printed dimensions and page layout to remain stable when he returned to buy new sheets. ${ }^{31}$

In themselves, the nine editions used by Baldwin imply little about their chronology, notwithstanding some evidence of staff deterioration, a subject that awaits further research. However, we learn much about their relationship by watching Baldwin's evolving notational habits and letter formation. Changes in his script and evolution in the repertory he copied - for instance, the inclusion of motets by Byrd composed during the 1580s - allow us to discern the chronology of the editions. Thus it is now almost certain that Baldwin's project started with a gathering he finally placed near the centre of the bound partbooks. This layer, copied largely on the paper I designate as 'FOX', was written informally, in a cursive secretary hand, and probably at speed, with little concern for elegance. ${ }^{32}$ The inclusion of largely obsolete Catholic ritual works by John Sheppard, Thomas Tallis, John Redford and their contemporaries may imply that Baldwin set out to preserve rare repertory that might otherwise be lost to posterity. Another early layer, copied wholly on the paper designated as 'APE', was made in each partbook from six sheets folded and nested together to create bulky quires of twenty-four leaves. ${ }^{33}$ Later layers, richer in music by William Byrd, are smaller and more regular, being typically made from a quired pair of folded sheets (eight leaves). By this stage, Baldwin's script has acquired greater elegance and consistency, with a higher proportion of stable italic letter-forms, much more like the work of an organised scribe.

The third partbook set, McGhie/T389, differs from both Dow and Baldwin in its diverse contents, which are variously sacred and secular, texted and untexted, and copied in layers by assorted unknown hands. ${ }^{34}$ To a modern reader this collection is frankly a jumble, and hard to comprehend. However, study of the printed papers used in this set of partbooks suggests that it may in fact unite unrelated fascicles made independently by different people for different purposes, and conjoined only at a relatively late stage. ${ }^{35}$ Their union would have been enabled by their common use of editions of the Tallis-Byrd quarto paper. The diversity of the fascicles might suggest that the contents were copied and used by a community such as a family, a school, or a professional group such as a company of waits. Whoever they were, the scribes could evidently source fresh batches of their printed music paper over the course of years or even decades. Uniformity of appearance may therefore not have mattered to them, in the way that it probably mattered to Baldwin, and definitely did to Dow. Instead, uniformity in McGhie/T389 may merely reflect the tight regulation of printed music papers during the twenty-one-year span of the Tallis-Byrd monopoly.

From all this, it should be clear that a Tallis-Byrd brand existed, and is ultimately defined by its staves, irrespective of how they might be placed in the forme in any edition of a design, whether quarto or folio. Figure 2.1 shows five of these staves as they occur in a randomly chosen page of McGhie/T389. ${ }^{36}$

Can these same staves also be found embedded in English books of printed polyphony? Many sixteenth-century music printers placed blank staves at the foot of pages where the notation does not fill all the available space. They did this partly for aesthetic reasons, partly because, during printing, a well-filled forme stopped the platen from dipping into unsupported areas, causing uneven printing or inking. ${ }^{37}$ As it happens, the Tallis-Byrd staves resist such comparative research, because only one book of polyphony was published in 


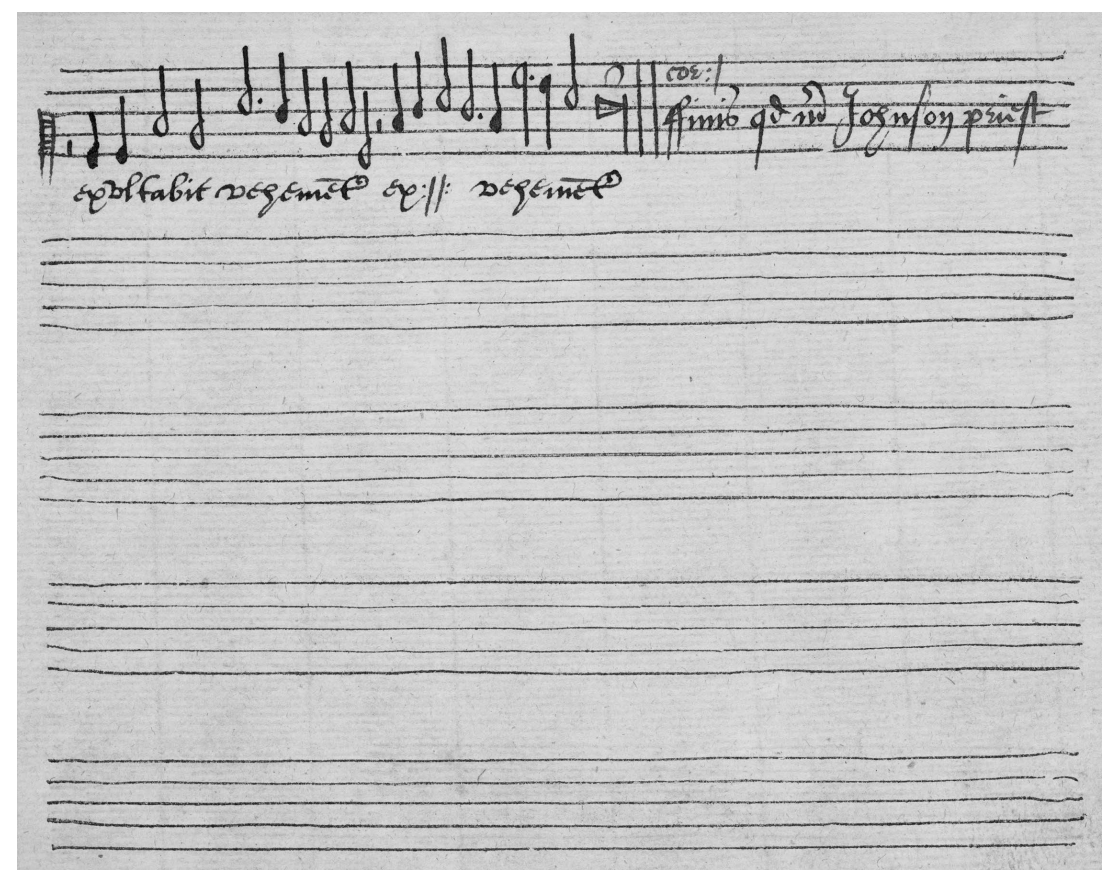

Figure 2.1 Oxford, The Bodleian Libraries, Tenbury MS 389, p. 63: quarto music paper printed by the 'integral-staff' method, as issued under the terms of the Tallis-Byrd licence of 1575-1596, here in the edition designated by the three-letter name 'POT'. The five staves illustrated here, from highest to lowest, are identified by the four-letter names AUNT, PLUM, BARD, OVAL and CHUM. Note especially the splays, breaks and other imperfections that allow each staff to be individually identified.

Reproduced by permission of The Bodleian Libraries, Oxford. The page can be viewed and enlarged using a high-resolution image at the DIAMM website.

England between 1575 and 1588, and its blank staves were assembled using the 'cast-staff' method; see Figure 2.2, which shows a sample page of Tallis and Byrd's Cantiones ... sacrae (London: Thomas Vautrollier, 1575; RISM 15753). Many sixteenth-century printers used segments of cast type to create blank staves in their books of polyphony, presumably because cast-type staves were quick and easy to set, could be adjusted in width to match the polyphony, and ensured consistency of appearance with the music itself. ${ }^{38}$ Using these same cast staff-segments, Vautrollier could have printed music paper, though no example has yet come to light. Instead, the printer(s) of the Tallis-Byrd papers, like English printers before and after them, used the integral-staff method. Nonetheless, the theoretical possibility of overlap between printed music papers and printed polyphony exists for printers in continental Europe. Did key figures in sixteenth-century music printing, such as Petrucci, Attaingnant, Gardano and Susato, issue music papers using the integral-staff method? If so, were the identical staves ever used in their books of polyphony? These questions lead to the second case study.

\section{Quarto music papers in the Bayerische Staatsbibliothek, Munich}

Unlike their English equivalents, sixteenth-century European printed music papers have not been systematically studied. The following discussion therefore locates some of the research opportunities that exist, and also points to challenges facing potential researchers 


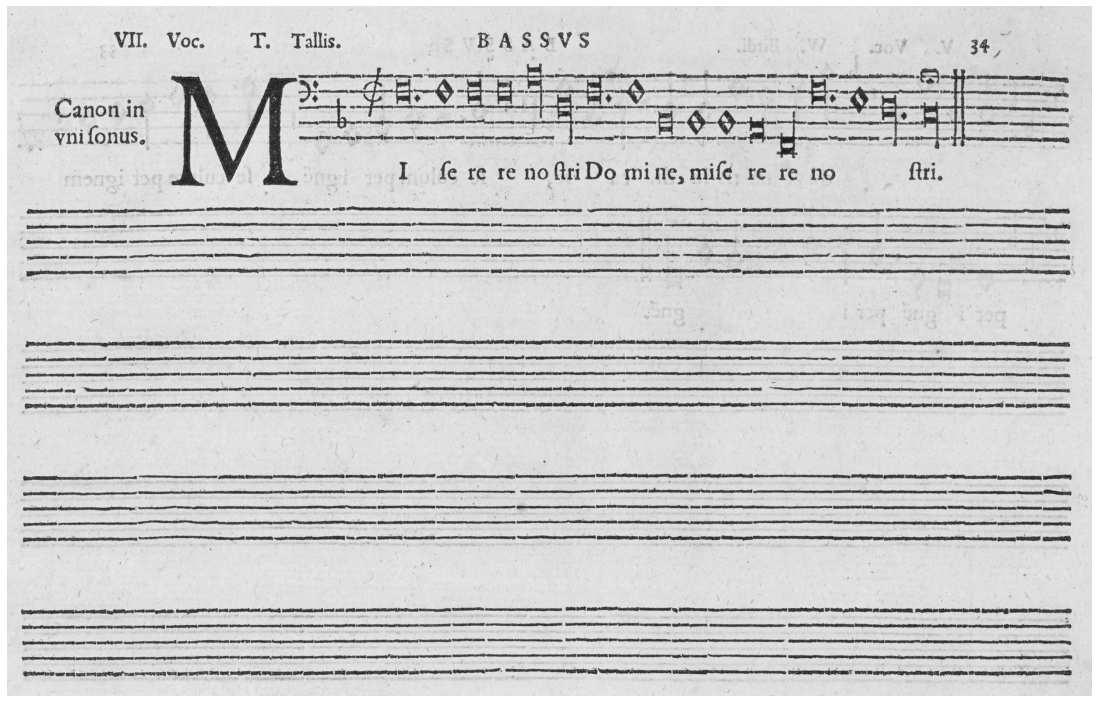

Figure 2.2 Blank staves printed using the cast-type method, as found in Thomas Tallis and William Byrd, Cantiones quae ab argumento sacrae vocantur (London: Thomas Vautrollier, 1575; RISM 1575³), Bassus, sig. H1vi reproduced from Oxford, Christ Church, Mus. 983.

Reproduced by permission of the Dean and Chapter of Christ Church, Oxford. A high-resolution image of this page is viewable on the DIAMM website. When magnified, the cast-type staff-segments can be discerned.

in this field. The sample papers discussed here are drawn from the collections of the Bayerische Staatsbibliothek, Munich. They make good subjects for introductory study, partly because important preliminary work has been done on them by Marie Louise Göllner (drawing on earlier research by Julius Joseph Maier) and JoAnn Taricani, partly because digital images can be accessed and freely downloaded from the Staatsbibliothek's website. ${ }^{39}$ In preparation for writing this study, the items mentioned below were inspected at the Staatsbibliothek to verify that their staves were indeed printed, not hand-ruled. Otherwise, all the research described below was done from digital images. In part, this has been made possible by the Staatsbibliothek's policy of showing a ruler at the end of its digital files, which allows screen images to be enlarged to life size. All measurements cited below have been derived in that way. They should therefore be verified against the original documents before being used for further research.

A good point of entry is the set of five partleaves bearing the anonymous lament O mater nostra, catalogued by Göllner as Mus. MS 1503b, no. 15 (fol. 14), and viewable on the Staatsbibliothek's website as part of Mus.ms. 1503b. ${ }^{40}$ This work, unique to these partleaves, commemorates Queen Anna Jagiełło, wife of Ferdinand I and sister-in-law to Charles V, who died on 27 January 1547. The piece was presumably written soon after her death. Because of its text, Albert Dunning classified it as a ceremonial motet (Staatsmotette), and floated the idea that it might have been sung at the queen's funeral in Prague, or at memorial events held in her honour in Vienna in February $1547 .{ }^{41}$ Its text is expressed in somewhat awkward Latin as a dialogue between the dead queen, her widowed husband and their three eldest sons, Maximilian (aged nineteen when his mother died), Ferdinand (aged seventeen) and Charles (aged six). In the Munich partleaves, the top two voices, both notated in $\mathrm{C} 1$ clef, are headed 'Pars Caroli' and 'Pars nostri principis Ferdinandi' respectively; the tenor (C3 clef) is 'Pars Maximiliani' (Figure 2.3), and the bass (F3 clef) 'Pars nostri regis Ferdinandi'. The fifth voice (C3 clef), headed 'Pars reginae Annae', remains 
silent until the words 'O my wife' ('O mea uxor'), where it joins the others in singing 'O my husband, it is too sad [to live] grieving and singing' ('O mi marite, deplorando et cantando nimium grave est'). Most unusually, $O$ mater nostra was copied by five different hands, each supplying one partleaf.

The printed music paper used for these partleaves can be dated c. 1547 on grounds of the lament copied on it. Göllner and Taricani report that the paper itself bears a watermark associated with either Augsburg or nearby Landsberg am Lech. ${ }^{42}$ They also suspect that these partleaves, together with others now in Munich, once belonged to the Augsburg bibliophile Hans Heinrich Herwart (1520-1583), whose music library survives largely intact within the holdings of the Bayerische Staatsbibliothek. To these facts we can now add a new one: the staves were printed by the 'nested' method. In the late 1540s, two Augsburg printers were actively involved in music printing, Melchior Kriesstein and Philipp Ulhart the Elder. When they printed music from type (rather than woodcut), both printers used only founts of nested music type. ${ }^{43}$

Three further items now in Munich are bibliographically related to these partleaves. All were copied on music papers printed using the nested method, all apparently descend from Herwart's library, and all share a scribal concordance with O mater nostra. Their copyist, still unidentified, has been designated 'Scribe J' by Taricani. ${ }^{44}$ Scribe J, who copied the 'Pars Maximiliani' in O mater nostra (Figure 2.3), copied two further sets of partleaves, each containing a Latin-texted song. He also contributed to a slender set of partbooks containing two motets, one of which is by Johannes (or Christian) Hollander. (On this indeterminacy, see below.) Between them, the four items copied wholly or partly by Scribe J make use of three different designs of 'nested' printed music paper. All use papers with watermarks associated with Augsburg or Landsberg. In combination, these details suggest that music papers were printed in Augsburg in the late 1540s.

Scribe J's music papers are best viewed online, using the Staatsbibliothek's digital images. From them, it can be seen that the two partleaf sets copied solely by him demonstrably use

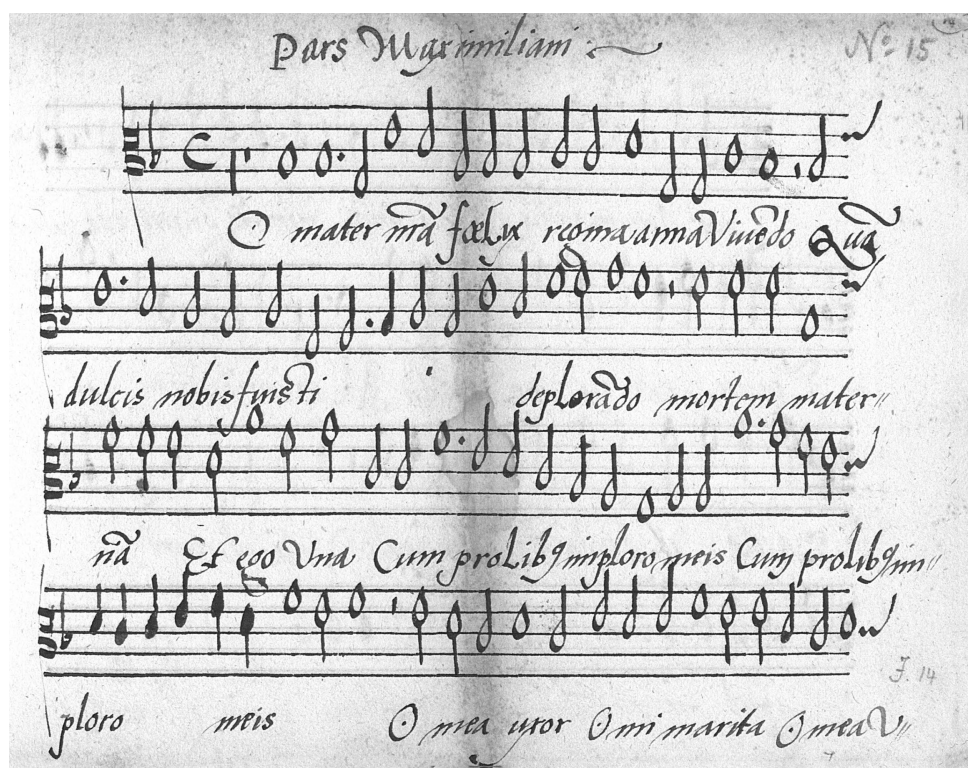

Figure 2.3 Tenor of anon., O mater nostra.

Source: Munich, Bayerische Staatsbibliothek, Mus. MS 1503b, no. 15, Tenor partbook, fol. $14^{\mathrm{r}}$. 
paper drawn from a single edition of one design, because the pattern of rule-distribution within their staves is identical. One set, made from bifolia, contains the anonymous fourvoice song Non eadem facies anni. ${ }^{45}$ The second set, made from single leaves, bears what may be the chorus of an unidentified four-voice work, opening with the words Arrentes [arentes?] irrigate fauces. ${ }^{46}$ These two partleaf sets use paper printed with four staves to the page; staff-height is approximately $13 \mathrm{~mm}$, and the top staff is not indented. ${ }^{47}$ This design therefore contrasts with the printed paper used for O mater nostra (Figure 2.3), which has a much taller staff-height of $17.5 \mathrm{~mm}$, and an indented top staff. The fourth item by Scribe J (Mus. MS 1505) uses yet another design of printed paper, again with staff-height of $13 \mathrm{~mm}$, but now with five staves to the page, and the top staff indented. Mus. MS 1505 is a set of six partbooks, each made from a single sheet folded into a four-leaf gathering. It features two unascribed motets, copied collaboratively by several hands, including Copyist J. ${ }^{48}$ The first motet, Tulerunt Dominum (à 6), is otherwise unknown. The second, Benedic Domine domum istam (à 5), has printed concordances, the earliest of which is Susato's Liber quintus ecclesiasticum cantionum quinque vocum (RISM $1553^{12}$ ), where the piece is attributed to 'Cristianus hollande' in the index, and to 'Ioannes de Hollande' in the music pages.

Several details link Scribe J's printed music papers to Kriesstein and Ulhart's printed polyphony. The main link is one of production technique. In their publications, Kriesstein and Ulhart always built their blank staves out of segments of nested rules, and never used the integral-staff method. It follows that they might also have used nested staves for any printed papers they produced. The second link is staff-height. In general, Kriesstein and Ulhart used music fonts with staff-heights of 9 or $11 \mathrm{~mm}$. However, a single extant publication by Ulhart, a broadsheet surviving in a single known copy, uses a larger font with staffheight of $13 \mathrm{~mm}$, exactly matching two of the printed papers used by Scribe J. ${ }^{49}$ The Ulhart broadsheet, which bears Sixt Dietrich's puzzle-canon Laudate Dominum omnes gentes (RISM A/1: D 3019; vdm 1176), is dated 1547, and may commemorate the imperial diet held in Augsburg in 1547-1548. We recall that the lament for Queen Anna, O mater nostra, was also dated tentatively to 1547. All these details together suggest strongly that music papers in a variety of designs were being printed in Augsburg by the late 1540s. This enterprise could have been led by Sigmund Salminger, the driving force behind the music printed by Kriesstein and Ulhart. ${ }^{50}$ Salminger is usually characterised as being a music editor, but it is possible that he was also a publisher, and therefore an entrepreneur.

Sixteenth-century Augsburg was a major trading centre and a distribution hub. Were its printed music papers being exported and used elsewhere? This seemingly straightforward question in fact leads into one of the most severe challenges facing research in this field: no comprehensive list or database exists of sixteenth-century music manuscripts. The nearest we have is the Census-Catalogue. The Illinois project was researched largely from surrogates such as microfilms, so it was not always alert to the presence of printed staves. Its coverage of manuscripts copied from mid-century onwards is highly selective. Having been published in book form, it is not searchable electronically - though its descriptions have now been incorporated into DIAMM, which does have a search facility. Meanwhile, various examples of sixteenth-century printed music paper have been found in manuscripts that were not included in the Census-Catalogue. Ideally, all these examples would be recorded in a dedicated database of early printed music papers, to which researchers could report new information as it comes to light; but no such collaborative database has yet been established. In short, a research opportunity exists here.

What benefits might be had from such a database? Its main uses would be to aid research in provenance history, and to shed light on the full range of music-related printed 
products that were available for sale in the sixteenth century. If printers across Europe did indeed issue music papers, and if those printers can be identified by analysing their papers, then useful facts may emerge about the provenance of manuscripts copied on those papers. This point is developed below by looking closely at one last item in the Bayerische Staatsbibliothek.

D-Mbs Mus. MS 1508 is an important source of chansons, copied in the 1540s, and known once to have been owned by Herwart. ${ }^{51}$ Its contents are entirely copied on printed music papers. ${ }^{52}$ These books' provenance is disputed: the prevailing view is that they come from either France or the Low Countries, but JoAnn Taricani has argued instead that they were probably copied in Augsburg. ${ }^{53}$ None of the music paper in these partbooks bears a watermark. What can study of the printed staves add to the debate?

D-Mbs Mus. MS 1508 was conceived from the start as a six-partbook chansonnier in three layers. It opens with a large collection of works for four voices, proceeds into a much shorter layer of works for five voices, and ends with a still shorter one for six voices. The maker of the partbooks acquired at least seventy-four sheets of music paper in quarto format, with staves printed by the integral-staff method, six staves to a page. In the discussion below, this product is called Paper X. All the sheets belong to a single edition, so probably they were bought as a single batch, in the same way that Robert Dow bought matching sheets to make his partbooks. The copyist, designated Scribe A by Taricani, named the four main partbooks 'Cantus', 'Altus', 'Tenor' and 'Bassus', and allocated sixteen sheets to each, but only six sheets to the much smaller 'Quinta pars', and a mere four to the 'Sexta pars'. ${ }^{54}$ The sheets were folded into four-leaf gatherings, the gatherings abutted (that is, not quired together), cut at the upper edges, and given signature letters (' $\mathrm{A}^{\prime},{ }^{\prime} \mathrm{B}^{\prime}$, ' $\mathrm{C}$ ', etc.), written in the bottom right-hand corner of the first recto of each gathering. Figure 2.4 shows the first page of Cantus sig. I. Into this structure, Scribe A copied sixty-two chansons for four voices (numbered by a later hand as '1-62'), twelve five-voice chansons ('83-104') and eleven sixvoice chansons ('111-121'), leaving some pages unused. He or she seems to have copied the contents partly in batches from chansonniers printed in Paris by Attaingnant and in Lyons by Moderne. From that evidence, Taricani argues that the partbooks came into existence 'sometime about 1542-43'. 55

The books were then expanded both physically and in terms of repertory by the copyist Taricani calls Scribe B. (Six other hands, Scribes C-H, subsequently added more pieces.) In particular, Scribe B set out to develop the five-voice layer, but needed extra pages to do this. He or she therefore acquired and inserted new gatherings, made from two closely related designs of another printed quarto paper, here called Papers Z1 and Z2. These too have six staves to a page, but otherwise they bear little resemblance to Paper X. Their staff-lines are thicker, the staves are longer, the width of the text-block varies between pages, and the staves are not always carefully justified at left and right. To the casual viewer they do not even look printed, and indeed Taricani thought that they were hand-ruled. ${ }^{56}$ In short, Papers Z1 and Z2 do not obviously match the brand of Paper X. They could have been made by a different printer in a different place at a different time.

However, papers Z1 and Z2 can in fact be identified. Their ragged appearance and imperfect justification are reminiscent of music books printed in Lyons by Jacques Moderne. A search through digital images of Moderne's publications from about 1542, also available at the Bayerische Staatsbibliothek's website, quickly revealed that the metal-rule staves used to print Papers Z1 and Z2 were also used to fill out pages of Moderne's Quintus liber mottetorum ad quinque et sex et septem vocum (RISM $1542^{5}$ ). Figure 2.5 shows a typical page 


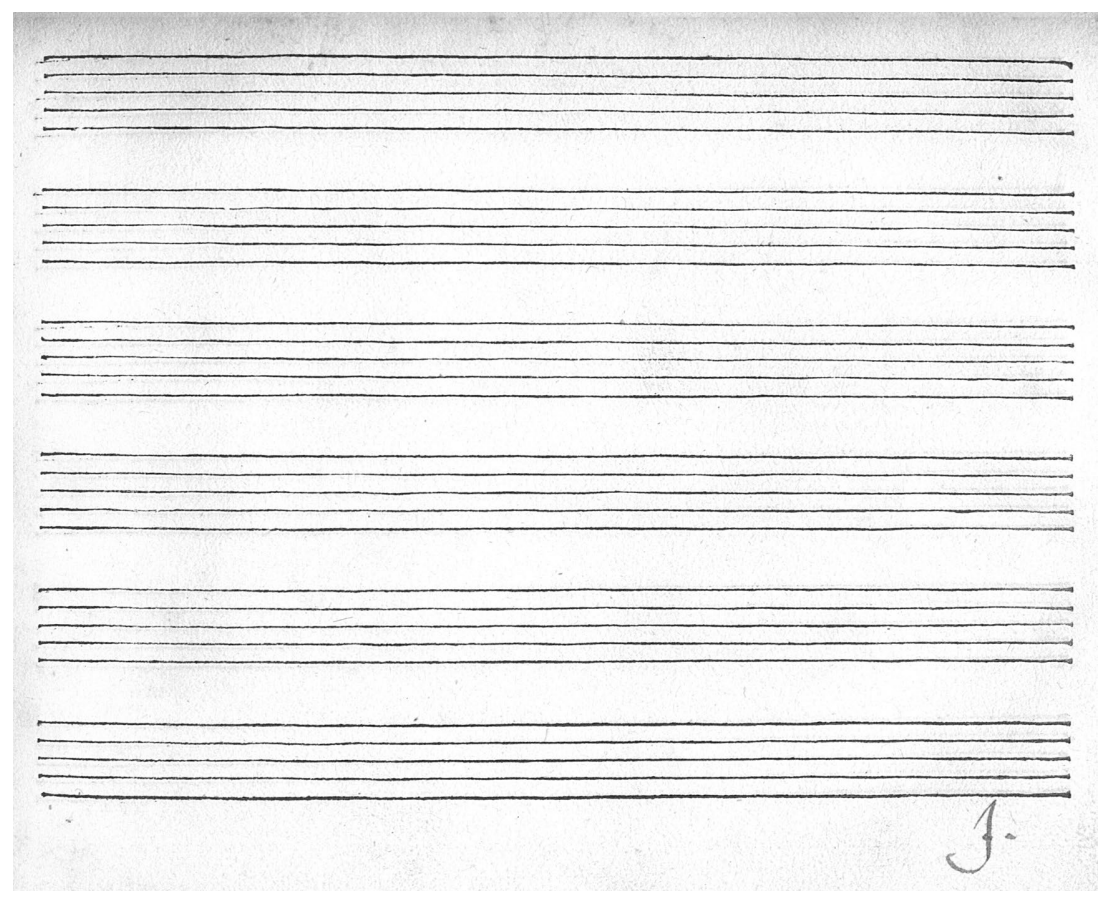

Figure 2.4 A page of Paper X.

Source: Munich, Bayerische Staatsbibliothek, Mus. MS 1508, Cantus partbook, fol. $47^{\mathrm{r}}$.

of Paper Z2 from Mus. MS 1508. It should be compared with Figure 2.6, which shows a page from Moderne's Quintus liber mottetorum. Note that the second and third staves in Figure 2.5 (Mus. MS 1508) are identical to the first and third blank staves of Figure 2.6 (RISM 15425). They were printed using the same metal rules, though in different states of damage. This discovery generates a new research opportunity. If the progressive deterioration in Moderne's blank staves were to be more closely examined - a task not attempted here - then it might be possible to prove that Paper Z2 was printed after RISM $1542^{5}$, but before another dated Moderne edition; this would allow us to date Paper Z2 with reasonable confidence.

The identity of the person who printed Paper X, the main design used in Mus. MS 1508, remains unclear. In theory, any firm that had access to the materials needed to print staves could have made this product, or indeed any other printed music paper. In practice, evidence exists to show that music papers were at least sometimes manufactured by (or for) printer-publishers with a known interest in music. ${ }^{57}$ This may have been for reasons of retail sale and distribution: a firm that produced, sold and marketed printed music might logically extend its product range to include printed music paper, and indeed become known as a supplier of music stationery. As a working hypothesis, therefore, music printers should be reckoned strong candidates for making and supplying printed music papers.

The quality of Paper $\mathrm{X}$ is superior to that used by Moderne; compare Figure 2.4 (Paper X) and Figure 2.5 (Moderne's Paper Z2). The metal rules used for Paper X are finer, and the staves are carefully justified at both the left- and right-hand margins. By comparison, Moderne's design looks decidedly rough. There is no reason to suspect that Paper X was manufactured by Moderne's competitors in Lyons, the Beringen brothers, because 


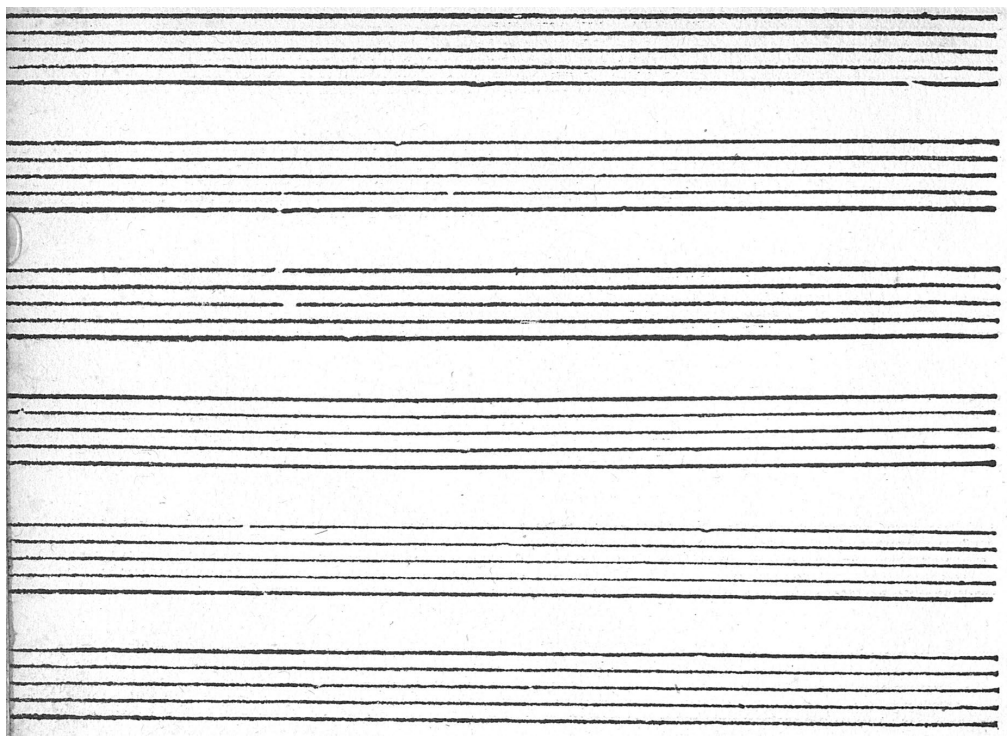

Figure 2.5 Paper Z2. Note the imperfections in staves 2 and 3, and compare them with the first and third blank staves of Figure 2.6, which were printed using the same brass rules. In Mus. MS 1508, all leaves of Paper Z2 have been trimmed at one margin.

Source: Munich, Bayerische Staatsbibliothek, Mus. MS 1508, Quinta Pars partbook, fol. 23v .

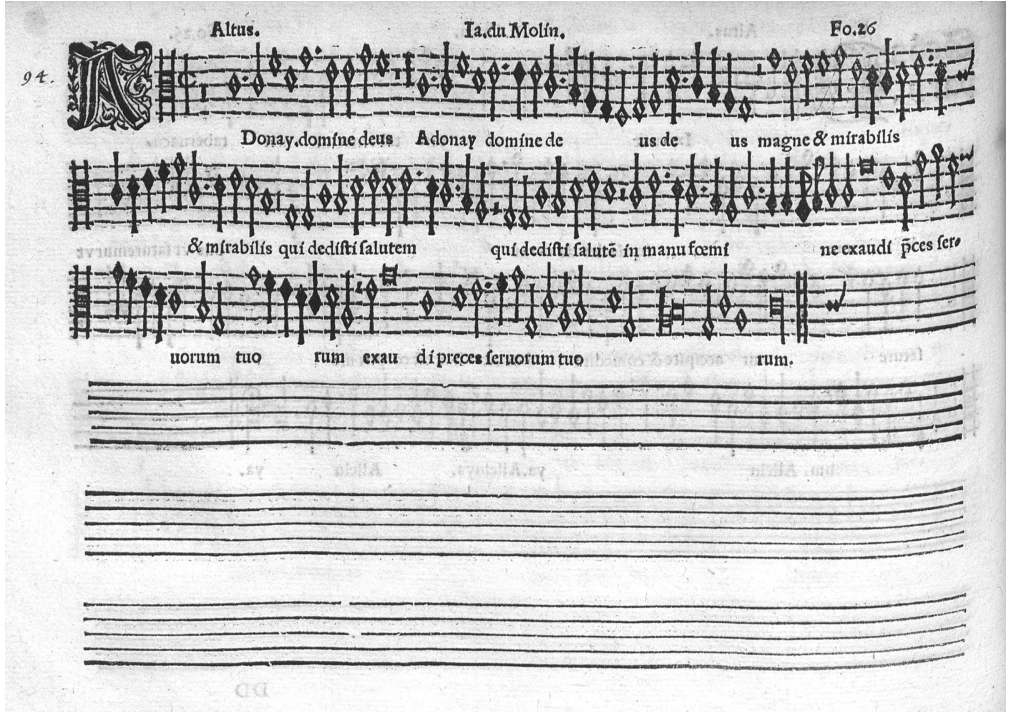

Figure 2.6 Quintus liber mottetorum ad quinque et sex et septem vocum (Lyons: Jacques Moderne, RISM $1542^{5}$ ), Altus partbook, p. 26; Note the imperfections in the first and third blank staves, and compare them with those of Figure 2.5, staves 2 and 3, which were printed using the same brass rules. In this image, curvature of the staves at the right-hand side arises from tightness of binding at the gutter edge.

Source: Munich, Bayerische Staatsbibliothek, $4^{\circ}$ Mus. pr. 201, tract 5. 
they used only nested music fonts, and therefore assembled blank staves using the nested method. However, Paper $X$ is made by the integral-staff method.

An obvious candidate as printer of Paper $X$ would be Pierre Attaingnant. He definitely manufactured music papers, though they remain unresearched. Herwart purchased many of Attaingnant's publications. ${ }^{58}$ However, the evidence provided by Paper $X$ may suggest otherwise, on two counts. First, Attaingnant's four known music fonts have staff-heights variously of 10,14, and $17.5 \mathrm{~mm} .{ }^{59}$ By contrast, Paper $X$ has a staff-height of $12 \mathrm{~mm}$. Second, a few quires of printed paper possibly printed by Attaingnant are bound together with some of Attaingnant's chansonniers of 1535-1536 in F-Pm 30485A. ${ }^{60}$ They have a staff-height of 10 $\mathrm{mm}$. This matches the staff-heights of Attaingnant's two main music fonts, but not Paper X.

Another conjecture worth considering is that Paper $\mathrm{X}$ was made by Tylman Susato, music printer in Antwerp from 1543, whose editions Herwart also collected. Susato's earliest publications use a font of nested type with a staff-height of $12 \mathrm{~mm}$, which exactly matches that of Paper X. ${ }^{61}$ Moreover, from the start of his career Susato filled out his pages of polyphony with blank staves made from continuous metal rules, also with a staff-height of $12 \mathrm{~mm}$. He therefore combined two technologies, nested type for the mensural notation, integral staves as filling material; see Figure 2.7, from Susato's Le cincquiesme livre contenant trente et deux chansons a cincq et a six parties (Antwerp: Tylman Susato, RISM 1544 ${ }^{13}$ ). The metal rules used for the staves of Paper $X$ are uniformly fine, and are carefully leftand right-justified on every page. The same high standards of production are evident in

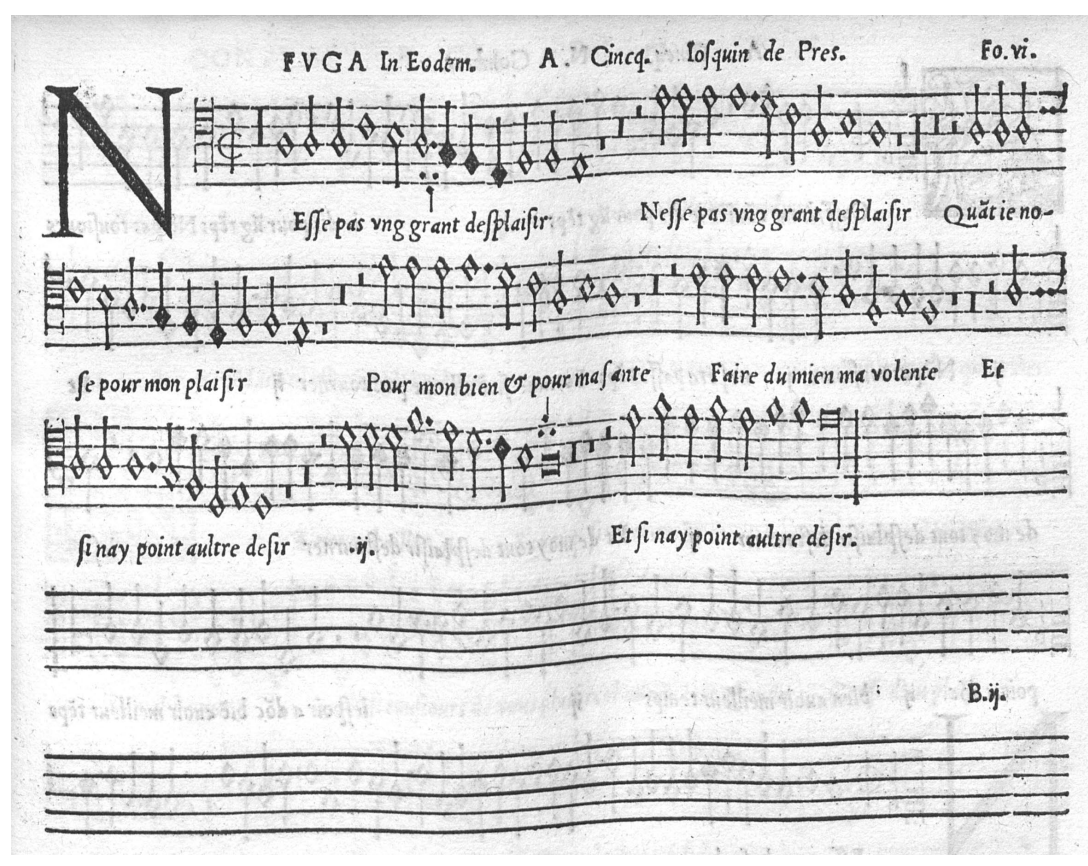

Figure 2.7 Le cincquiesme livre contenant trente et deux chansons a cincq et a six parties (Antwerp: Tylman Susato, RISM 1544 ${ }^{13}$ ), Contratenor partbook, fol. $6^{\text {r; }}$ The two blank staves at the foot of the page have each been printed from two segments of staff, one long, the second short. Susato's compositors often used this principle, possibly because it allowed slight flexibility when the staves were justified with the typeset music. The pages of this book are cockled, hence the wavy effect in this image.

Source: Munich, Bayerische Staatsbibliothek, $4^{\circ}$ Mus. pr. 201, tract 4. 
Susato's printed polyphony. Susato's first known publication bears the date of 1543; this aligns perfectly with the earliest possible date for initial music copying in Munich Mus. MS 1508.

However, a bid to link Paper $X$ with Susato runs against some significant obstacles. ${ }^{62}$ First, Paper X lacks watermarks, whereas Susato always used watermarked paper in his printed books. Admittedly the paper used for printing staves might have needed to be of a special kind in order to make it suitable for manuscript use, for example, to cope with ink absorption, and therefore differ from Susato's normal papers; but closer analysis of music papers would be required to test this hypothesis. Second, staff-length in Paper X is $164-166 \mathrm{~mm}$, whereas it is typically $160 \mathrm{~mm}$ in Susato's chansonniers of the 1540s. It would of course have been possible for the printer of Paper $X$ to have reserved those longer staves expressly for repeated printings of music paper, in the same way that Tallis and Byrd or their printer reserved a set of staves for this purpose; but Susato need not have been that printer. Above all, however, any attempt to attribute Paper X to Susato fails for a third reason: the actual staves used to print Paper $X$ do not occur in any polyphonic books printed by Susato in the 1540s. No direct link exists, as it does between Papers Z1-Z2 and Moderne's publications.

What does seem likely, however, is that the integral-staff method of printing blank staves, as found in Paper X, was in use by French and Flemish music printers by the mid1540s, but not by their German contemporaries. ${ }^{63}$ The case for an Augsburg provenance of D-Mbs Mus. MS 1508 thus does not look strong. None of the paper bears a German watermark; Papers Z1 and Z2 were definitely printed in Lyons by Moderne; the copyists' scribal habits, to quote David Fallows, 'are without question those of a born Francophone, with handwriting absolutely characteristic of mid-16th-century French sources' ${ }^{64}$ If anything, Mus. MS 1508 now seems more closely linked to Lyons, where Papers Z1 and Z2 were printed. This makes total sense: branches of the Herwart family resided and did business in that city. ${ }^{65}$ As for the dates of compilation, at present Paper $X$ yields no firm information, but Papers Z1 and Z2 do hold promise, because their staves were used multiple times by Moderne, and deteriorated over time. Closer study of them may point to a year of printing; this would provide an approximate date when Scribe B expanded Mus. MS 1508.

\section{Learning from printed staves}

The main lesson to be learnt from this study is that printed music papers can yield evidence about their place of origin, their date, and even their printer. ${ }^{66}$ For instance, we may learn something by identifying the manufacturing process, whether integral-staff, nested or cast-type, because different printers used different methods. The height of the staff needs to be known, because it may match staff-height in a printer's font of music type, and therefore point to or imply the printer's identity. Above all, however, latent evidence exists in every staff that can be visually distinguished from its neighbours, either because of the way it was made, or from damage subsequently done to it. Once we have identified individual staves, we can prove that a design of printed paper passed through more than one edition. When that happens, study of staff-placement allows us to distinguish the editions. Staff-deterioration may imply chronology. If a printer used his set of staves to print not only music paper but also partbooks, then his identity may be revealed by comparing those two categories of product. This has happened with Jacques Moderne, and as a result, we now know not only that he issued music paper, but also what it looked like. An investigation of staff-deterioration across Moderne's printed output might permit us to establish 
relative chronology or approximate dates not only for Papers Z1 and Z2, but also for those of Moderne's sets of partbooks that were issued without date of publication, such as the enigmatic Musicque de joye (RISM [c. 1550] $\left.{ }^{24}\right){ }^{67}$ Thus staff deterioration now becomes a topic that invites future research.

When two or more discrete items can be linked together through their shared use of the same staves or method of manufacture, then it becomes possible to affirm or propose the concept of brand, and to supply a base on which future research can build. For instance, comparison of papers - based on analysis of the staves and watermarks - now allows us to speak with confidence about a Tallis and Byrd brand, a Moderne brand, and probably an Augsburg brand. Through further research, it may also be possible to identify an Attaingnant brand, working outwards from the printed paper bound into F-Pm 30485A (briefly mentioned above).

Knowledge of brand can contribute to biography. A case in point is Derrick Gerarde, active in the mid-sixteenth century, who made extensive use of printed papers. Gerarde is a shadowy figure, undocumented in archival sources, and known mainly from his compositions. Susato printed a few works attributed to 'Gerardus' between 1544 and 1558, but the majority are unique to Gerarde's six holograph partbook sets, which survive in various states of completeness in The British Library. ${ }^{68}$ These books are important because they contain by far the largest known cache of autograph copies of music by any sixteenthcentury composer. But they are also mysterious, because so little is known about Gerarde's life and career. Between them, Gerarde's partbooks contain at least five different designs of printed music paper. ${ }^{69}$ One of them, with a distinctive ornamental border of printer's flowers, has long been known to have been printed in England. Recently it has been dated more precisely to c. 1567-1572, giving us for the first time firm evidence of Gerarde's whereabouts at a particular period..$^{70}$ An obvious next step would be to research the other printed papers used by Gerarde. They have plainer designs, not otherwise recorded in Tudor sources. It would be worth investigating whether any of them were printed on the European mainland. Gerarde's partbooks can now be viewed online in high-resolution digital images. ${ }^{71}$ A rich research opportunity exists here.

Looking to the future, scope exists for the creation of a collaborative online catalogue of music papers and tablature grids known to have been printed in at least the sixteenth and seventeenth centuries, and possibly later too. Such a catalogue would need to be international in its coverage, because the papers themselves could move across Europe over time, whether in unused state as stationery for sale, or in the hands of the musicians and collectors who owned and used printed-paper products. It would be essential for this catalogue to be image-rich, because the printed staves themselves transmit so much key evidence. The catalogue would need to link with data about sixteenth-century music fonts, and indeed might even intersect with detailed analyses of those fonts. ${ }^{72}$ It would need to be searchable by at least four criteria: (1) manufacturing process (integral-staff method, etc.); (2) design (number of staves, indentation of top staff, etc.); (3) measurements (staff-height, staff-width); and (4) watermarks. Items with shared brand characteristics would ideally be grouped together, irrespective of the library locations where those items are now physically kept. Above all, though, it would need to supply users with hypertext links to the ever-expanding world of online digital images, through which intensive research in this field has been made possible in the first place. Such a collaborative catalogue or database might reasonably be hoped to supply relevant data for locating the likely origins of previously obscure sources, and to provide a much broader view of music printing, creation and consumption than has previously been achieved. 


\section{Notes}

1 I am indebted to Nicolas Bell, Laurent Guillo, Martin Ham and Eric Jas for their comments on a draft text of this study. Existing writings about printed music papers include Fenlon and Milsom, 'Ruled Paper Imprinted'; Butler, 'Printed Borders'; and for seventeenth-century France, Guillo, 'Les papiers à musique'. The present study distinguishes between 'staff/staves' and 'tablature grid' to signal differences of function: a staff is used to specify pitch, whereas a tablature grid specifies the courses of a plucked instrument.

2 For documentary references to the sale or use of ruled papers in France, Spain and Italy, see Van Orden, Materialities, 44-45 (France), 50 (Spain), and 73 (Italy). For images of two ruled papers printed or used in the Low Countries, see Schreurs, Anthologie van muziekfragmenten, 127 (lower image) and 130-131. For English papers, see Fenlon and Milsom, 'Ruled Paper Imprinted'. Sanna Raninen (personal communication) kindly alerted me to examples of Swedish manuscripts with printed staves.

3 This licence, which also gave Tallis and Byrd exclusive rights to print music in England and import printed music into England, is discussed most fully in Tallis \& Byrd: Cantiones Sacrae 1575, Introduction.

4 Fenlon and Milsom, 'Ruled Paper Imprinted'.

5 On Herwart's collection, see Slim, 'The Music Library'.

6 For discussion of the staves used when printing music by double or multiple impression, see Duggan, Italian Music Incunabula, 49-64, and Boorman, Ottaviano Petrucci, 118-121.

7 According to Moxon, Mechanick Exercises, 26-27, brass rules were made by joiners, and were hardened by planishing or annealing to minimise the risk of bowing. If combined to form staves or tablature grids, the rules may have been set in grooves cut into wooden blocks.

8 In theory, a bend or splay in a metal staff-line could be rectified with pliers. In reality, however, printers of music papers seem to have ignored such blemishes, allowing them not only to survive, but then to be joined by further imperfections - hence the 'evolving identity' of each staff. A small dent or break in a metal staff-line might have been harder to remedy.

9 The terms 'nested' and 'linear' were introduced by Donald Krummel in English Music Printing, 49-50. For discussions of the process of setting nested mensural music type, see especially Forney, 'Tielman Susato', 112-117 and 151-154; also McDonald, 'Printing Hofhaimer', 70-72.

10 Krummel's term 'linear type' denotes a single-impression music font in which every sort includes a segment of five-line staff. The principle was apparently first used by John Rastell in London in the early 1520s, but was made famous by the Parisian printer Pierre Attaingnant.

11 Cast staves and staff-segments for printing plainchant are discussed in Duggan, Italian Music Incunabula, 55.

12 Peter Stallybrass shrewdly observes that printers have always relied on 'little jobs' for cash turnover, and that many such 'little jobs' fall into the category of 'blanks', that is, single-sheet (or single-leaf) printed works designed to be filled in by hand; Stallybrass 'Little Jobs', 340-341. Printed music papers perfectly exemplify those points.

13 I propose use of the term 'edition', rather than 'state', because the latter bibliographical term implies changes made to the contents of a forme during the course of printing, prior to those contents being broken up and distributed. 'Edition', conversely, implies that the forme has been freshly composed, even if using exactly the same staves as in earlier and later editions.

14 For English music papers printed between c. 1530 and c. 1575, see Fenlon and Milsom, 'Ruled Paper Imprinted'.

15 Arber, A Transcript, 111.

16 Ibid., 144.

17 Leedham-Green, Books in Cambridge Inventories, 1: 337, item 465.

18 Rodger, 'Roger Ward's Shrewsbury Stock', 252, item 102. Other 'paper bookes' listed in this inventory (items 511-519) might also refer to ruled music paper, but the descriptions are too vague to be sure.

19 Another possibility is that the staves were set permanently into the spacing furniture, and therefore naturally resumed their relative positioning when returned to the forme. I am grateful to Nicolas Bell for this suggestion.

20 Scope exists for watermark evidence to be taken into account. For some preliminary work on this in the Tallis-Byrd quarto music papers, see Butler, 'Creating a Tudor Musical Miscellany'. 
21 Described with an inventory and summary collation in Bray, 'The Part-Books'. See also the online description and inventory at the Christ Church Library Music Catalogue website. High-resolution digital images can be accessed at the DIAMM website, and a facsimile edition is in preparation for the series DIAMM Publications.

22 Facsimile and full discussion in The Dow Partbooks. High-resolution digital images can be accessed at the DIAMM website.

23 High-resolution digital images can be accessed at the DIAMM website. A detailed discussion of these partbooks is forthcoming in Butler, 'Creating a Tudor Musical Miscellany'.

24 See Tallis \& Byrd: Cantiones Sacrae 1575, xxviii-xxx.

25 Eccles, 'Bynneman's books', 87, item 146. An English pound ( $£$ ) was worth 20 shillings (s), and a shilling worth 12 pence/pennies (d); so $£ 1=240 \mathrm{~d}$.

26 Blayney, The Stationers' Company, 1: 101-102.

27 Barnard and Bell, 'The Inventory', 11-14.

28 This estimate is supported by a receipt written by William Byrd for payment of two shillings for 'three quyres of partician [partition] paper', probably in 1576; see Harley, William Byrd, 47. Assuming that this refers to printed music paper, the value of each sheet was approximately $0.34 \mathrm{~d}$.

29 Watt, Cheap Print, 11-12.

30 Full details, together with collation diagrams and an inventory, will feature in the forthcoming facsimile edition of Baldwin. The outline analysis of gathering structure shown in Bray, "The PartBooks', 184-188, is largely accurate, but supplies too little information to be useful for detailed research, and was also drawn up before the partbooks were paginated.

31 An equivalent system operates in our own day: some music publishers sell forms of music stationery that have been available in stable formats for many decades. For instance, the UK firm of Novello has long produced a numbered series of 'Manuscript Books' with configurations of staves and quality of paper that never significantly change.

32 This layer opens with John Sheppard's responsory [Justi autem] in perpetuum (no. 90). In GB-Och Mus. 979, the layer is made solely from edition FOX; in the other partbooks of the set, FOX is mixed with sheets of editions ELK and HEN. A full analysis of the editions of printed papers used in Baldwin will appear in the introduction to the forthcoming DIAMM facsimile of these partbooks.

33 This layer opens with Robert Parsons's O bone Jesu (no. 54). When Baldwin subsequently joined the various fascicles together, he excised the start of this piece, and re-copied its opening at the close of a fascicle made from the later edition CAT. By doing so, he achieved a seamless continuity of contents from CAT into APE; but as a result, Baldwin's scribal hand changes character during the course of this work. See, for instance, GB-Och Mus. 979, p. 108 (last page of CAT) and facing p. 109 (first page of APE): the right-hand page of the opening (109) shows an earlier state of Baldwin's hand than the re-copied left-hand page (108).

34 In both partbooks, the printed staves begin at p. 17, following a layer copied on hand-ruled staves.

35 This is suggested by the fact that copying of some pieces coincides with the first recto of a fresh edition of printed staves. For instance, Robert Johnson's Domine in virtute tua was copied at the start of a four-leaf gathering made from a sheet of the edition designated as POT (at McGhie, p. 61, and T389, p. 59). The edition designated BUG, which starts at p. 17 in both partbooks, is also found in Baldwin, commencing at (for instance) GB-Och Mus. 979, p. 149. Baldwin used BUG to extend an earlier layer made from edition APE (commencing at GB-Och Mus. 979, p. 109), in which he had already copied motets by Byrd composed probably in the mid-1580s, such as Tristitia et anxietas. This may imply that edition BUG was itself printed in the mid-1580s. If so, then evidence from Baldwin can be used to point to a possible copying date for one layer of McGhie/ T389. However, it should not be assumed that the layers of McGhie/T389 were necessarily copied in the order in which they were eventually bound.

36 The same image can be viewed online at the DIAMM website, where a ruler is shown, allowing the image to be zoomed to life-size, and its dimensions accurately measured. Magnification also allows every defect to be viewed in minute detail.

37 Butler, 'Printed Borders', 178, drawing on the expertise of Paul Nash, tutor in hand-press printing at The Bodleian Libraries, Oxford.

38 Segments of cast four-line staff were also commonly used to print the red staves for plainchant in liturgical books produced by the double-impression method. Presumably this is because the often 
complex mise-en-page of liturgical books required staves to be of many different lengths, and this was most easily achieved by using type segments to set the staves.

39 Göllner, Tabulaturen und Stimmbücher; Taricani, 'A Chansonnier'.

40 Göllner, Tabulaturen und Stimmbücher, 61-62; online reference numbers were accurate at the time of writing (May 2019). For an overview of the phenomenon of partleaves (loose single leaves or bifolia, one for each performer), and discussion of the term 'partleaf', see Milsom, 'The Culture of Partleaves'. The Bayerische Staatsbibliothek holds the largest known cache of sixteenth-century examples.

41 Dunning, Die Staatsmotette, 224-226.

42 Göllner, Tabulaturen und Stimmbücher, 60; Taricani, 'A Chansonnier', 110 (watermark E), 115, 117, and $121 \mathrm{fn} 35$. Digital images of these and other watermarks mentioned below can now be viewed on the Bayerische Staatsbibliothek's website, accessed under the call-numbers of the items to which they relate.

43 This conclusion was reached by viewing digital images of all the music items known or thought to have been printed by Kriesstein and Ulhart, as catalogued in the $v d m$ database. It is unclear whether Kriesstein and Ulhart both owned fonts of nested type, or shared them with one another, or drew on fonts owned by third parties. For some discussion of this, see Krummel, 'Early German Partbook Type Faces', 83-87; also Röder and Wohnhaas, 'Der Augsburger Musikdruck', 301-310.

44 Taricani, 'A Chansonnier', 99 and 121.

45 D-Mbs Mus. MS 1503b, fols. 12-13, no. 14. Göllner, Tabulaturen und Stimmbücher, 61, which reports that this song also occurs in RISM $1561^{1}$ and later manuscript sources. Images can be viewed online as part of Mus.ms. $1503 \mathrm{~b}$.

46 D-Mbs Mus. MS 1503b, fol. 5, no. 6. Göllner, Tabulaturen und Stimmbücher, 61-62. Images can be viewed online as part of Mus.ms. $1503 \mathrm{~b}$.

47 It is impossible to be precise about measurements, partly because of inconsistencies in the inking of the staff-lines, which themselves may vary slightly in height and length, partly because of shrinkage of the paper, which may not be consistent within a batch. On measurement, see especially Forney, 'Tielman Susato', 109-111; Krummel, 'Early German Partbook Type Faces', 97-98; and Guillo, Les éditions musicales, 377-378. On paper shrinkage, see most recently Blayney, 'A Dry Discourse', 391.

48 Göllner, Tabulaturen und Stimmbücher, 67-68. This book is viewable online at Mus.ms. 1505.

49 This font is described in Krummel, 'Early German Partbook Type Faces', 87, typeface no. 7.

50 On Salminger, see Jacoby, 'The Salminger Anthologies'; Röder and Wohnhaas, 'Der Augsburger Musikdruck', 301-310; Röder, 'Innovation and Misfortune', 469-477; and especially James, 'Transforming the Motet'.

51 Description and inventory in Göllner, Tabulaturen und Stimmbücher, 68-76. Provenance: Slim, 'The Music Library', item no. 236. This manuscript is viewable online as Mus.ms. 1508.

52 The presence of printed staves is not noted in the description of D-Mbs Mus. MS 1508 in CensusCatalogue, 2:220-221. This information is therefore also absent from the DIAMM description.

53 Taricani, 'A Chansonnier', especially Chapter III, at 181-201.

54 None of the copyists of Mus. MS 1508 has been identified. The distribution of hands is listed in Taricani, 'A Chansonnier', 139, and sample images are supplied at 140-147.

55 Taricani, 'A Chansonnier', 199-201.

56 Ibid., 135.

57 For instance, in late Tudor England music paper was definitely printed by (or for) Thomas East, who at the time was London's principal music printer; see Fenlon and Milsom, 'Ruled Paper Imprinted', and Butler, 'Printed Borders'. The evidence that Moderne printed music paper as well as music is outlined in the present article; the evidence for Attaingnant follows below. The Tallis-Byrd monopoly of 1575 effectively gave the two men control over all three principal retail opportunities for notated music: printing music, selling imported music, and selling music paper.

58 For a document of 1554 referring to the sale of Attaingnant's papier reglé, see Heartz, Pierre Attaingnant, 191.

59 Heartz, Pierre Attaingnant, 72.

60 F-Pm Rés. $8^{\circ} 30485$ A. The presence of printed music paper within this volume is mentioned in Heartz, Pierre Attaingnant, 286, and in Census-Catalogue, 3: 37. 
61 Forney, 'Tielman Susato', 129, music type A.

62 I am indebted to Martin Ham for the following observations.

63 This conclusion has been reached after viewing digital images of a wide selection of German partbooks printed in the 1530s and 1540s, as catalogued in the $v d m$ database. Printers who owned or used fonts of linear type, such as Formschneider, Rhau and Berg \& Neuber, created blank staves by abutting short segments of cast type. Printers who owned or used fonts of nested type, such as Petreius, Kriesstein and Ulhart, built blank staves out of nested staff-lines.

64 New Josquin Edition 28; Critical Commentary, 351-352.

65 Taricani, 'A Chansonnier', 49-50.

66 Of course, date of manufacture does not necessarily equate with date of subsequent use by a copyist. Nonetheless, when a substantial manuscript has been made wholly from a single edition of a printed music paper, as is the case with Dow (using an edition of the Tallis-Byrd quarto design) and the first layer of repertory in Munich Mus. MS 1508 (using Paper X), then the date of copying may well correlate with the date of acquisition of a printed paper, and, in turn, with its approximate date of printing. The numerous editions of the Tallis-Byrd quarto design imply that print-runs were relatively short, and indeed it could have been more convenient and economical to print new editions afresh when needed, rather than store large quantities of sheets printed as a single edition.

67 Various publication dates between 1542 and 1556 have been proposed for Musicque de joye; see Pogue, Jacques Moderne, 182-183. However, nobody has yet looked at staff-deterioration as a latent source of evidence. For Moderne's other undated publications, see the items listed in parentheses in Pogue, Jacques Moderne, 272-278.

68 Royal Appendix MSS 17-22, 23-25, 26-30, 31-35, 49-54 and 57, surveyed in overview in Milsom, 'Nonsuch', 162-164; suggestions made there for other possible Gerarde holographs can now largely be excluded. The fullest discussion to date of Gerarde and his manuscripts is Milledge, 'The Music of Dyricke Gerarde', which includes transcriptions of all Gerarde's known compositions found in English manuscript sources.

69 Fenlon and Milsom, 'Ruled Paper Imprinted', Table 1 (p. 146), designs 1c, 1f, 1h, 1i and 1j.

70 GB-Lbl Royal Appendix MS 57; see Butler, 'Printed Borders', especially the summary at 201.

71 At the time of writing, the images can be accessed through DIAMM, but not at The British Library's own website. Gerarde revised many of his compositions; his methods can be followed by comparing the online images with the score transcriptions in Milledge, 'The Music of Dyricke Gerarde', downloadable from Durham University Library's website.

72 To date, nobody seems to have created a 'virtual font' of a music typeface by extracting sample sorts from digital images. Scope exists for the creation of a database of all sixteenth-century music fonts, searchable by (for instance) clefs, mensuration signs and directs.

\section{References}

Arber, Edward. A Transcript of the Registers of the Company of Stationers of London: 1554-1640 A.D., vol. I. London: privately printed, 1875.

Barnard, John, and Maureen Bell. 'The Inventory of Henry Bynneman (1583): A Preliminary Survey'. Publishing History 29 (1991): 5-46.

Blayney, Peter. 'A Dry Discourse on Wet Paper (and Ink)'. The Library, 7th series 18 (2017): 387-404.

Blayney, Peter. The Stationers' Company and the Printers of London 1501-1557. 2 vols. Cambridge: Cambridge University Press, 2013.

Boorman, Stanley. Ottaviano Petrucci: Catalogue Raisonné. Oxford and New York: Oxford University Press, 2006.

Bray, Roger. 'The Part-Books Oxford, Christ Church, MSS 979-983: An Index and Commentary'. Musica Disciplina 25 (1971): 179-197.

Butler, Katherine. 'Creating a Tudor Musical Miscellany: The McGhie/Tenbury 389 Partbooks'. Music $\mathcal{E}$ Letters, forthcoming. 
Butler, Katherine. 'Printed Borders for Sixteenth-Century Music or Music Paper and the Early Career of Music Printer Thomas East'. The Library, 7th series 19 (2018): 174-202.

The Dow Partbooks: Oxford, Christ Church Mus. 984-988, facsimile with introduction by John Milsom. Oxford: DIAMM Publications, 2010.

Duggan, Mary K. Italian Music Incunabula: Printers and Type. Berkeley, Los Angeles, and Oxford: University of California Press, 1992.

Dunning, Albert. Die Staatsmotette 1480-1555. Utrecht: A. Oosthoek's Uitgeversmaatschappij N.V., 1969.

Eccles, Mark. 'Bynneman's Books'. The Library, 5th series 12 (1957): 81-91.

Fenlon, Iain, and John Milsom. "'Ruled Paper Imprinted": Music Paper and Patents in SixteenthCentury England'. Journal of the American Musicological Society 37 (1984): 139-163.

Forney, Kristine K. 'Tielman Susato, Sixteenth-Century Music Printer: An Archival and Typographical Investigation'. PhD dissertation, University of Kentucky, 1978.

Göllner, Marie L., ed. Tabulaturen und Stimmbücher bis zur Mitte des 17. Jahrhunderts. Bayerische Staatsbibliothek. Katalog der Musikhandschriften 2. Munich: G. Henle Verlag, 1979.

Guillo, Laurent. Les éditions musicales de la Renaissance lyonnaise. Paris: Klincksieck, 1991.

Guillo, Laurent. 'Les papiers à musique imprimés en France au XVII siècle'. Revue de musicologie 87 (2001): 307-369.

Harley, John. William Byrd, Gentleman of the Chapel Royal. Aldershot / Burlington VT: Ashgate, 1997.

Heartz, Daniel. Pierre Attaingnant, Royal Printer of Music: A Historical Study and Bibliographical Catalogue. Berkeley and Los Angeles: University of California Press, 1969.

Jacoby, Stephen D. 'The Salminger Anthologies'. PhD dissertation, The Ohio State University, 1985.

James, Charles Aaron. 'Transforming the Motet: Sigmund Salminger and the Adaptation and Reuse of Franco-Flemish Polyphony in Reformation Augsburg'. PhD dissertation, University of Rochester, 2016.

Krummel, Donald W. ‘Early German Partbook Type Faces'. Gutenberg-Jahrbuch 60 (1985): 80-98.

Krummel, Donald W. English Music Printing 1553-1700. London: The Bibliographical Society, 1975.

Leedham-Green, Elisabeth. Books in Cambridge Inventories: Book Lists from Vice-Chancellor's Court Probate Inventories in the Tudor and Stuart Periods. 2 vols. Cambridge: Cambridge University Press, 1986.

McDonald, Grantley. 'Printing Hofhaimer: A Case Study'. Journal of the Alamire Foundation 7 (2015): 67-79.

Milledge, Anthony. 'The Music of Dyricke Gerarde'. PhD dissertation, Durham University, 2001.

Milsom, John. 'The Culture of Partleaves: Peterhouse and Beyond'. In Music, Politics and Religion in Early Seventeenth-Century Cambridge: The Peterhouse Partbooks in Context, edited by Scott Mandelbrote, forthcoming.

Milsom, John. 'The Nonsuch Music Library'. In Sundry Sorts of Music Books. Essays on The British Library Collections Presented to O. W. Neighbour on His 70th Birthday, edited by Chris Banks, Arthur Searle, and Malcolm Turner. London: The British Library, 1993, 146-182.

Moxon, Joseph. Mechanick Exercises on the Whole Art of Printing (1683-4), edited by Herbert Davis and Harry Carter. 2nd edition. Oxford: Oxford University Press, 1962.

New Josquin Edition 28: Secular Works for Four Voices, edited by David Fallows, Critical Commentary. Utrecht: Koninklijke Vereniging voor Nederlandse Muziekgeschiedenis, 2005. 
Pogue, Samuel. Jacques Moderne, Lyons Music Printer of the Sixteenth Century. Geneva: Librairie Droz, 1969.

Röder, Thomas. 'Innovation and Misfortune. Augsburg Music Printing in the First Half of the 16th Century'. Yearbook of the Alamire Foundation 2 (1997): 465-477.

Röder, Thomas, and Theodor Wohnhaas. 'Der Augsburger Musikdruck von den Anfängen bis zum Ende des Dreissigjährigen Krieges'. In Augsburger Buchdruck und Verlagswesen. Von den Anfängen bis zur Gegenwart, edited by Helmut Gier and Johannes Janota. Wiesbaden: Harrassowitz Verlag, 1997, 291-321.

Rodger, Alexander. 'Roger Ward's Shrewsbury Stock: An Inventory of 1585'. The Library, 5th series 13 (1958): 247-268.

Schreurs, Eugeen. Anthologie van muziekfragmenten uit de Lage Landen (Middeleeuwen - Renaissance). Leuven and Peer: Alamire Foundation, 1995.

Slim, H. Colin. 'The Music Library of the Augsburg Patrician, Hans Heinrich Herwart (1520-1583)'. Annales musicologiques 7 (1964-1977): 67-109.

Stallybrass, Peter. "'Little Jobs": Broadsides and the Printing Revolution'. In Agent of Change: Print Culture Studies after Elizabeth L. Eisenstein, edited by Sabrina Alcorn Baron, Eric N. Lindquist, and Eleanor F. Shevlin. Amherst and Boston: University of Massachusetts Press, 2007, 315-341.

Tallis, Thomas \& William Byrd: Cantiones Sacrae 1575, edited by John Milsom. Early English Church Music 56. London: The British Academy, 2014.

Taricani, JoAnn. 'A Chansonnier from a Library in Renaissance Augsburg: Munich, Bayerische Staatsbibliothek, Mus. Ms. 1508'. PhD dissertation, University of Pennsylvania, 1986.

van Orden, Kate. Materialities: Books, Readers, and the Chanson in Sixteenth-Century Europe. New York: Oxford University Press, 2015.

Watt, Tessa. Cheap Print and Popular Piety, 1550-1640. Cambridge: Cambridge University Press, 1991. 